\section{Retail Trade Restructuring Paths on the Fringes of a Strong Region: the Case of Lower Lombardy, Italy (2001-2019)} Restructuring Paths on the Fringes of a Strong Region: the Case of Lower Lombardy, Italy (2001-2019). Bollettino della Società Geografica Italiana serie 14, 3 Special Issue: 127-146. doi: 10.36253/bsgi-991

Copyright: (c) 2020 M.A. Clerici. This is an open access, peer-reviewed article published by Firenze University Press (http://www.fupress.com/bsgi) and distributed under the terms of the Creative Commons Attribution License, which permits unrestricted use, distribution, and reproduction in any medium, provided the original author and source are credited.

Data Availability Statement: All relevant data are within the paper and its Supporting Information files.

Competing Interests: The Author(s) declare(s) no conflict of interest.

\section{Percorsi di ristrutturazione del commercio al dettaglio ai margini di una regione forte: il caso della Bassa Lombardia, Italia (2001-2019)}

\author{
Maria Antonietta Clerici \\ Dipartimento di Architettura e Studi Urbani (DAStU), Politecnico di Milano, Italy \\ E-mail: maria.clerici@polimi.it
}

\begin{abstract}
The "commercial revolution" driven by the spread of large-scale retail is always spatially differentiated. Even within an economically developed region, such as Lombardy, significant differences can be seen between territories with regard to the structure and evolution of the distribution network. The paper considers the case of Lower Lombardy, a vast rural area which includes 424 municipalities split into 4 provinces (Pavia, Lodi, Cremona and Mantua). An eccentric outlook is adopted compared to trade geography studies, which are usually focused on large urban areas, overlooking what occurs in peripheral contexts. The restructuring of the distribution network between 2001 and 2019 is investigated, highlighting how the municipalities of the southern part of Lombardy witnessed different evolutionary trajectories in relation to their demographic size and their position in the urban network. The image of trade decline, often associated with rural areas, is too simplistic and conceals different processes, which restructure the relationships internal to those areas. The paper also highlights a concerning process of weakening of the proximity commercial supply: are we moving towards the formation of food deserts?
\end{abstract}

Keywords: retail trade, liberalisation, rural areas, urban hierarchy, food deserts. 
evidenzia inoltre un preoccupante processo di indebolimento dell'offerta commerciale di prossimità: si va verso la formazione di food deserts?

Parole chiave: commercio al dettaglio, liberalizzazione, aree rurali, gerarchia urbana, food deserts.

\begin{abstract}
"There was a time when the idealised image of a rural community almost existed. Every small town would have its bank, its post office and its store. Every village would have its church, its shop and its pub. No more. The rationalisation and closure of both private and public services in rural communities has been one of the most visible manifestations of contemporary countryside change" (Woods 2005, 96).
\end{abstract}

\section{Introduction}

When looking at the transformation dynamics of retail trade, large urban areas catalyse our attention. Here, the "creative destruction" generated by the spread of large retail complexes is more shocking. Competition between businesses is fierce and a multipolar supply network has now formed, on the geographical level, which makes the ordered centre/periphery hierarchy of the past, long protected by territorial planning, unrecognisable (Borchert 1998). The historical cores of the larger cities are emblematic of a strong capacity of reinvention of trade, in reaction to the altered competitive context (Wrigley, Lowe 2002). However, a view too focused on urban areas risks relegating to the background what occurs elsewhere. This work shifts attention to the rural areas, connoted by a specific trade environment, with pressures and challenges to be addressed which differ greatly from those that affect large cities. Investigating the evolution of trade in these places means considering a small aspect - at first sight, marginal - within the broader issue of territorial gaps and the socio-economic development of peripheral contexts, which continues to concern the decision-makers at different levels of government.

In Italy, after the "Bersani Decree" (Italian Legislative Decree 114/1998), there was some public commitment to supporting the distribution network in rural areas, but, unlike other countries, there is no solid thread of studies on trade issues in these areas: there have been few works and they mostly relate to mountain areas (Preite 2003; Morandi 2005; Pilotti, Giovanelli 2010). An unforgiveable oversight. In rural economies, the trade sector generates many jobs, gives visibility to handicrafts and typical local products, and is a precious source of revenue for public bodies (Vias 2004; Adkisson, Pallares 2016). Without shops, the quality of life reduces irreparably, particularly in more isolated regions (Fertner et al. 2015). In many countries, efforts have been made to guarantee an albeit minimal commercial presence in rural areas, also with a view to stabilising the resident population. The most successful measures include the opening of multifunctional emporiums offering a broad range of services (Amcoff et al. 2011; Karlsson 2012). In rural areas, in addition, trade has even more marked social value than in the large cities. Cabras and Lau (2019) compare shops and other essential services to fully-fledged "third spaces" and to community hubs, demonstrating how their closure reduces social cohesion. In these places, trade is an icon of identity, a signaller of vivacious communities and of the "rural idyll" (Scarpello et al. 2009).

Low population density, settlement dispersion and often considerable distances from town centres which provide essential services for community life are the main factors that affect the structure and the system of relationships within rural areas. It is not easy, here, to guarantee an adequate supply of public and private services, therein including those of trade (OECD 2010). Looking at the long-term dynamics of trade geography in developed countries, rural regions stand out for their fragility. They are affected by a reduction in shops that is more pronounced than that experienced by other territories, a process linked in a two-way relationship to the depopulation that has struck many areas, particularly those in remote locations (the process is, however, also active in more dynamic areas). This image of inexorable trade decline is too simplistic and should be re-discussed. Besides, even on the front of development policies, it is now clear that rural areas make up an articulated universe (ESPON 2013). The evolutionary trajectories of trade in rural areas, in comparison with those of other central territories, must therefore be investigated more carefully. But attention must also be paid to the dynamics internal to each area, following the restructuring of the system of relationships at local scale generated by the development trajectories of the individual municipalities. Even concerning the involvement of mass retail chains, rural communities do not find themselves in the same situation (Bahn, Abebe 2017; Chaze 2017).

The contribution deals with all this, taking as its field of investigation the quadrant to the south of Lombardy, including the provinces of Pavia, Lodi, Cremona and Mantua: 7,880 square km, 424 municipalities, 1.6 million inhabitants in 2019. 
The aim of the work is twofold. Firstly, the transformation of the distribution network over the space of twenty years after the entry into force of the "Bersani Decree" is recognised. By liberalising trade, this measure altered the market balances: the effects were strong in densely urbanised areas - where a significant increase in large retail complexes was recorded - but also extended to the peripheral contexts. The 2008 economic crisis was a further shock that challenged trade resilience. We will attempt to understand how, in Lower Lombardy, transformation forces affected the municipalities in relation to their demographic size and their position in the settlement system. The second aim of the work is to assess the extent to which the contraction of the distribution network in the period in question (2001-2019) led to situations of excessive rarefaction of the food supply. We will touch upon a crucial issue. In many developed countries, in rural areas, phenomena of food deserts are present which, although difficult to measure, pose serious problems of spatial justice. Guaranteeing an adequate proximity service - to which the elderly and those who are less mobile are more sensitive - is an objective found in the "Bersani Decree". The issue is also important in Lombardy, a region that, in the national panorama, boasts the lowest density of shops compared to the population ${ }^{1}$, by virtue of the intense development of large-scale retail.

The work is split into two parts. The first (section 2) contextualises the problem of trade in rural areas, focusing on the interweaving of factors that threaten the stability of the distribution network, until generating phenomena of food deserts. The second part of the work concerns the case of Lower Lombardy. After having outlined its settlement features (section 3), we investigate the transformation of the distribution network between 2001 and 2019 (sections 4-5), noting that there are still very clear traditional connotations and how the overcoming of the centre/periphery hierarchy is less advanced compared to other parts of the region. Finally, we focus on the rarefaction of the commercial supply of food which may be a prelude to the formation of food deserts (section 6).

\section{The decline of trade in rural areas: a trodden path?}

The statement of the geographer Michael Woods, at the start of this essay, captures a situation now common to many countries, including Italy: the gradual rarefaction of public and private services in rural communi-

${ }^{1} 8.9$ shops/1,000 inhabitants in 2017, against a national value of 11.2 . ties. The process does not spare commercial businesses, having negative repercussions on the habitability of the places. It is a problem that has been known for some time, but that continues to concern policymakers and to fuel studies and debates (Massal 2018; Twardzik, Heffner 2019). Even international cooperation networks are having to contend with this issue: the Save Rural Retail project, activated in 2018, is emblematic, federating public bodies of seven European countries, in the search for effective solutions to encourage the survival of small commercial enterprises in rural areas ${ }^{2}$. Demographic decline, which affects many of these places, is a key factor that compromises local commercial supply, particularly where there are no compensatory tourist flows, which guarantee adequate profits to traders.

The development of large-scale retail is a further serious threat to the maintenance of trade in rural places. Although preferably located close to large town centres, large retail complexes extend their influence to a broader extent over the territory, leading to the closure of many small shops providing a service close to residences. Therefore, even for foodstuffs, the distances to be travelled to access supply locations have significantly increased. Many rural areas have become food deserts (Amcoff 2017; Behjat et al. 2017; Blanchard, Lyson 2002; Furey et al. 2001; Marshall et al. 2018; Scarpello et al. 2009; Smith, Morton 2009; Wrigley 2002).

The practice of out-shopping, favoured by the increasing mobility of the population, is another important factor influencing retail trade patterns in rural areas. Local shops are no longer the main destinations for purchases, but merely satisfy supplementary requirements; the majority of spending flows elsewhere, depressing local entrepreneurial vitality and reducing tax revenues for public bodies. Out-shopping mainly involves the younger, educated and mobile population. The elderly and low-income individuals, hindered in their mobility, are more dependent upon local shops, even if the offer is less varied and the prices higher, due to the greater logistical and supply costs that weigh on rural retailers (Broadbridge, Calderwood 2002; Mullis, Kim 2011; Shannon 2016). Overall, the cited factors interweave to create a hostile environment for businesses, particularly in more isolated locations (Byrom et al. 2003).

In reality, the image of the relentless decline of retail trade in rural areas is too simplistic and unifying. Rath-

\footnotetext{
2 The project forms part of the INTERREG 2014-2020 Programme and has a budget of 1.7 million Euros. The lead partner is the Chamber of Commerce, Industry and Services of Teruel (Spain); another eight public bodies of Finland, Germany, Greece, Ireland, Poland, Spain and Sweden participate.
} 
er, there are different evolutionary processes, affected by geographical and local socio-economic conditions (Vias 2004; Paddison, Calderwood 2007). The foresight of policymakers and the capacity to attract investments also make a difference (Ayres et al. 1992).

The problems and dynamics of trade in remote areas are different from those that can be seen close to urban agglomerates. In the latter case, for example, competition between businesses is higher and out-shopping practices more frequent. To describe this diversity, McEachern and Warnaby (2006) introduced the concept of "relative rurality". Urban and rural do not contrast sharply; there is, rather, a continuum of situations, graduated by the changing combination of certain factors, such as population density, the services present, the structure of the settlement system and the distance between inhabited centres.

Specific attention has been paid to the role of medium and small towns (market towns) in rural contexts. Often, they lose out due to the attraction of metropolitan areas and demographic and productive decentralisation which strengthens even smaller inhabited centres, fuelling phenomena of settlement dispersion. However, compared to commercial services, there is no shortage of places that keep unaltered their role of polarity compared to the surrounding territories. Much depends on the geographical position of the individual cities, on the level of openness to large-scale retail and, last but not least, on the capacity to polarise jobs (in the public and private economy) which generate flows usable by the commercial businesses themselves (Marjanen 2000; Powe et al. 2007; van Leeuwen, Rietveld 2011; Chaze 2017).

\section{The case of Lower Lombardy}

For the geographer Turri (2000) the territorial area to the south of Lombardy, coinciding with the provinces of Pavia, Lodi, Cremona and Mantua, constitutes the "green heart" of the Po Valley megalopolis: an area mainly consisting of plains, fragmented into 424 municipalities (in 2019) and located on the left bank of the river Po, with the exception of two appendices (Oltrepò Pavese and Oltrepò Mantovano).

Lombardy, despite hosting a city (Milan) which exceeds a million inhabitants, is the land of small towns, a trait that connotes even more clearly the southern belt of the region. Here, in 2019, $82.5 \%$ of municipalities have fewer than 5,000 inhabitants, against a regional value of $68.7 \%$ (Tab. 1). However, the incidence of small towns is not homogeneous in the study area: it reaches the mini- mum in the province of Mantua (54.7\%), which, also for other aspects, is different from the rest of the territory (often starkly).

In Lower Lombardy demographic density is about half that of the region (197.3 against 421.6 inhab. $/ \mathrm{km}^{2}$ ) and a non-negligible share of the population (8.2\%) lives in nuclei and scattered houses, a legacy of historic forms of widespread coverage of the countryside which still remain today. Overall, it is not a remote rural area, given its vicinity to Milan and to the central urban backbone of the region extending between the foothills and the line of risorgive. Some areas, located close to the large infrastructural corridors, are classified by the regional territorial plan (2017) as "emerging polarities"3. There are also more isolated places, where the LEADER programmes are active, aimed at promoting socio-economic development through Local action groups (LAG) ${ }^{4}$.

Lower Lombardy's economic system is strongly linked to agriculture and to intensive farming. In terms of added value, the primary sector has a significant incidence with respect to the regional picture (4.5\% against $1.1 \%$ in 2017). The secondary sector is also over-represented, which revolves around agri-food and other specialisations, sometimes assuming typical configurations of industrial districts (particularly in Mantua).

As noted several times, in rural areas, population mobility is high. This is also confirmed in the case in question, with the sole exception of the municipalities of the province of Mantua, connoted by lower commuting rates than those of the region.

As early as in the Nineties of the last century, Lower Lombardy had recorded a good demographic increase (+2.4\% between 1991 and 2001). This also manifested in the 2001-2010 period: as previously, the population growth rate was higher than the regional rate $(+8.1 \%$ against $+6.3 \%$ : fig. 1 ). The municipalities close to Milan grew at a more intense rate. This geography highlights how large portions of the low plain have been affected by the wide-ranging decentralisation, around Milan, of the population and of economic activities. Equally intense, but less linked to Milanese affairs, is the increase in the province of Mantua. On the other hand, both the capitals of the province and the small more isolated municipalities lose population, particularly in Oltrepò Pavese: overall, few places. The picture changes significantly in the subsequent period (2010-2019) when the population growth rate stands at a value less than the regional rate

\footnotetext{
${ }^{3}$ Lodi-Crema-Cremona triangle, Mantua-Brescia-Verona triangle, Lomellina-Novara area.

${ }^{4}$ For the period 2014-2020, this was the LAG Oltrepò Pavese, Risorsa Lomellina, Oglio-Po and Terre del Po.
} 
$(+1.8 \%$ against $+4.8 \%)$. Large portions of Lower Lombardy, now, are witnessing a demographic decline, with high points in the more isolated areas (Oltrepò Pavese, Lomellina, Oltrepò Mantovano, Oglio-Po area). Phenomena of growth are very concentrated, involving the capitals, their surrounding belts, and, once again, the territorial area close to Milan.

\section{Different trajectories of transformation of trade}

To what extent does Lower Lombardy share this process of weakening of the distribution network that connotes many rural areas? The question is dealt with in this paragraph, investigating the transformation of retail trade between 2001 and 2017.

In general, in Italy, the liberalist change in trade governance, impressed by the "Bersani Decree" (1998), has had two effects, only partly counteracted by the 2008 economic crisis (Clerici 2019): 1) jobs in the industry increased, driven by the development of large-scale retail, with an inversion of the cycle of decrease recorded in the Nineties; 2) local units reduced, but at significantly lower rates than in the past.

These two trends can also be seen in Lower Lombardy. Here, however, the performances are not good (Tab. 2). Between 2001 and 2011, the reduction of local units $(-12.6 \%)$ was higher than that recorded at regional level $(-8.2 \%)$. The same occurred in the subsequent period (2012-2017) when the rate of change stood at a value double that of Lombardy $(-8.7 \%$ against $-4.3 \%)$. There are differences between the four provinces of the study area, and their positions, as to intensity of changes, have changed over time. However, they all performed worse than the region as a whole. In terms of employment, between 2001 and 2011, the expansive regional dynamic was followed, but with a more timid recovery $(+6.5 \%$ against $+14.2 \%)$. In the subsequent phase (2012-2017), the trajectories diverge: while, at regional level, workers further increased $(+2.3 \%)$, in the study area, the opposite happened (-1.9\%). This was the case in all provinces, except for Mantua. Overall, compared to the Nineties the differentials with respect to the regional figures increased: in Lombardy, the liberalisation of the retail sector seems to have accentuated the gaps between territories.

Employment dynamics should be followed closely as they involve a crucial problem. In many countries, liberalist attitudes in the governance of trade are justified both by the intention to improve efficiency in the sector and by the will to support employment, relying on largescale retail, which allegedly generates more jobs than it destroys (Viviano 2008). In the southern part of Lombardy, a particular situation has been produced. In all provinces, between 2001 and 2011, precisely as occurred at regional level, employment in trade increased. The trend of decline recorded in the previous decade was therefore inverted. A good result. But while, at regional scale, employment increased until surpassing, in 2011, the threshold of 1991, this did not happen in the study area. In 2011, the gap compared to twenty years earlier is approximately 3,000 workers. Given the declining dynamics of the 2012-2017 period, the gap further expanded (-3,500 workers in 2017 compared to 1991). Only the province of Lodi, over the course of the 2000s, regained the employment levels of 1991.

To analyse in more detail the evolution of trade, the municipalities of Lower Lombardy were split into four categories: 1) provincial capitals; 2) centres, or non-capital municipalities with over 10,000 inhabitants in 2019; 3) municipalities in the belts surrounding the two previous situations, located within a radius of $10 \mathrm{~km}$; 4 ) other municipalities. In that way, the existence or otherwise of a centre/periphery hierarchy in the transformation of the distribution network can be ascertained.

Centres and belts - particularly the former - boast the best performances: in both periods in question, they record smaller reductions of local units compared to the other types of municipalities and the area as a whole (but not compared to Lombardy: tab. 2). In terms of employment, the same situation arises again. It should be noted that centres and belts see an increase in workers between 2012 and 2017, albeit modest, but opposed to the general dynamic. These places, in addition, have a positive balance of employment in the long-term (19912011), which is further consolidated in 2017.

Centres and belts, as we will see below, have focused strongly on large-scale retail. The municipalities close to the larger cities have obtained benefits from the decentralisation of trade: an excellent example of the capacity to exploit the so-called mechanism of "borrowed size" (Meijers, Burger 2017). But, in addition, many centres, coinciding with municipalities with a certain demographic size, have not been less successful in attracting large sales structures within their administrative borders. At local scale, the vitality of historic centres has been jeopardised, but the long-term balance - in terms of local units and workers - is in any case better than that recorded by the capitals and by the more peripheral municipalities, which suffered the most negative effects of the development of large-scale retail.

This is important as it highlights how, in the Lombardy low plain, a centre/periphery hierarchy tends to be retained in the organisation of the territory which 
follows "christrallerian" principles (Emanuel 1990; Dematteis, Emanuel 1990; Mainardi 1997; Turri 2000). This does not mean that the hierarchy established by Christaller is unchanged. It has eased, but the process is not as disruptive as the one visible in the Milan area, where, over the 2000s, trade decentralisation has continued at an intense pace (Clerici 2019). This has interwoven with the redistribution of the population and economic activities, originating a "post-metropolitan" urban form in which the centre/periphery gradient has flattened (Balducci et al. 2017). In Lower Lombardy, on the other hand, trade decentralisation is of short-range and spreads around the main centres. It should be noted that the centres include municipalities (not capitals) with more than 10,000 inhabitants, medium-small cities, generally identified as polarities of the respective provinces in territorial plans; cities that, often, are classified as poles of local labour systems. Therefore, they are key points in the organisation of the territory. Trade contributes to strengthening their centrality, similarly to when it occurs for many market towns of other countries, at the centre of rural regions.

The breakdown of municipalities by demographic classes is a further key of interpretation which highlights the major difficulties of the smaller centres $(<5,000$ inhab.) in safeguarding their distribution network (Tab. 2). The demographic decline that has broadly affected these places has certainly not encouraged the survival of trade.

\section{The network of medium and large food sales structures}

In the liberalist climate of the 2000s, also in Lower Lombardy, large-scale retail earned new market spaces at the expense of small businesses. Assuming the classification of the "Bersani Decree", we follow the evolution of medium and large sales structures over the timeframe 2003-2019, focusing in particular on the food sector.

It is clear that medium sales structures (MSS) have an important role to play in Lower Lombardy: in 2019, a good $40.3 \%$ of the area's total sales surface was linked to this type of structure, with an appreciable difference from the regional figure (34.5\%). Food surface areas account for about a quarter of the total and in the period in question they increased at higher rates than the non-food areas, as also occurred at regional scale (Tab. 3). However, there are differences between the prices of the area as to evolutionary trajectories (Fig. 2). Mantua and Cremona have driven the development of MSS. For a long phase, after 2003, their growth rates were higher than the regional ones; they then reduced, until con- verging on the latter. Pavia and Lodi, on the other hand, display a more constant trend of growth in line with the regional rate.

The significant presence of small inhabited centres and the low demographic density, which connote the study area, push up the amount of MSS with respect to the population. As early as in 2003 all provinces, except for Cremona, had a density index higher than the regional one. However, the spatial distribution of MSS does not follow the same model. In the province of Mantua, the share of municipalities with these structures is very high (68.8\% in 2019). In the rest of the territory, on the other hand, the presences are sparse and involve only a small part of the municipalities, included between $26.5 \%$ (Cremona) and $31.1 \%$ (Pavia). Overall, in the period in question, the share of municipalities with food MSS increased from $27.6 \%$ to $34.0 \%$ of the total (from 117 to 144 municipalities). The increase recorded close to Milan was significant, where there was some demographic effervescence which opened new market spaces for enterprises.

Food MSS have made their entrance into many small municipalities $(<5,000$ inhab.), even though the share of surface area attracted is small (Tab. 4). These structures prefer larger centres; in particular, the municipalities with between 5,000 and 10,000 inhabitants significantly increased their incidence in terms of surface areas. Considering the position of the municipalities in the urban network, the attraction exercised by the capitals and the centres, where over half of the total surface areas are concentrated, is clear. But the value has reduced over time. There has been an outward push: the belt municipalities and above all the other municipalities, even more peripheral, have concentrated increasing shares of the overall surface area.

As regards large sales structures (LSS), the study area followed the regional trend: in the food sector, the growth was more intense between 2003 and 2011 $(+14.4 \%)$, but then, between 2011 and 2019, it reduced $(+2.2 \%)$. In both periods, however, the variation rates were lower than the regional ones. Considering the entire timeframe, the growth rate in the study area is 9 pp. lower than the Lombardy rate $(+17 \%$ against $+28 \%$ : tab. 3). The limited demographic load in the plain to the south of Lombardy has definitely hindered the advancement of LSS. But it is also important that those structures appeared well before the "Bersani Decree". In the mid-Seventies of the last century, one of the first Lombardy shopping centres was opened in Montebello della Battaglia (close to Voghera) ${ }^{5}$; other structures were built

\footnotetext{
${ }^{5}$ It is currently one of the largest shopping centres of Lower Lombardy with a GLA (Gross leasable area) of 33,400 sqm.
} 
over the course of the Nineties and saturated the local markets.

As already occurred for MSS, the aggregate data mask the different behaviours of the provinces (Fig. 2). Mantua is a case apart: strong rates of development higher than the regional ones, it contrasts with the other provinces, which were much more static (Cremona even sees a drop in surface areas). The localisation of food LSS is very concentrated. In 2019, they were present only in 39 municipalities (32 in 2003). Once again, the province of Mantua is detached from the others: the share of municipalities with structures of this type increases to 21.9\% (in 2019), well above what is recorded elsewhere, particularly in the provinces of Pavia and Cremona (where the value is 5\%). Considering these data together with those on MSS, one aspect is clear: the majority of municipalities have a distribution network linked to small stores. However, despite being distributed in a punctiform way, the larger structures have restructured the relationships between territories, even at a great distance: the sharp decline of local units highlighted in tab. 2 confirms this.

When looking at the location of food LSS, the siege of the larger town centres is a clear image. There is no intricate network of polarity that connotes the Milan area. The design is much more orderly. Around Lodi and Mantua there is stringent coverage: LSS are present in a good part of the municipalities of the belt, along the main roads that lead out to the territory. Elsewhere, the presences are punctual, although the surface areas involved are substantial, as in the cases of San Martino Siccomario (south of Pavia), Montebello della Battaglia (east of Voghera) and San Rocco al Porto (close to the regional border, north of Piacenza).

In this general context, the group of smaller municipalities $(<5,000$ inhab.) plays an important role, polarising about a third of the total surface areas (Tab. 4). Compared to 2003, the share has reduced by 4.8 pp., but remains significant, above all when compared with the modest concentration level of MSS. The municipalities in the bracket of 1,000-3,000 inhabitants are strongly attractive. However, even the capitals and the centres have a non-negligible incidence in the geography of LSS. The latter even increased their incidence (from 33.2\% to $37.3 \%$ between 2003 and 2019). These figures highlight how the drive to decentralise trade is strong but is contrasted by the larger town centres, which have also opened up to large-scale retail. Note the dynamism of the municipalities in the bracket of 5,000-10,000 inhabitants and above all that of the centres between 10,000 and 20,000 inhabitants: the intermediate layer of the urban armour is very vivacious in challenging both the historical supremacy of the capitals and the increased competition of many small municipalities.

\section{The rarefaction of food supply}

In the context outlined thus far, it is unclear how the level of commercial service to the population has changed. The distribution network of Lower Lombardy has weakened in the last two decades, but to what extent has this determined situations of criticality in supply, particularly food? The question is burning in the political sphere. Of course, competition between businesses must be encouraged, but an adequate proximity service must always be guaranteed, particularly in the smaller centres and in the areas with low settlement density. The aim is cited in the "Bersani Decree" and also inspires the governance of trade in Lombardy. Furthermore, the problem of the formation of food deserts, which involves many rural areas, is also intercepted.

The Lombardy region has introduced an index for assessing the level of commercial desertification, based upon which it is clear that the phenomenon is more pronounced in the small municipalities of the mountains and the plains (therein including the study area) ${ }^{6}$. Rather than use that index, we chose the Retail Capacity Index (RCI) developed by Bilková et al. (2018). It assesses the (positive or negative) difference with respect to the theoretical level of supply that each municipality should have based upon its population, taking account of the regional context and its evolution over time:

$$
R C I=[(S i-P i * S / P) / S i] * 100
$$

where $S i=$ supply in the municipality $i ; S=$ total supply of the region;

$P i=$ population resident in the municipality $i$; $P=$ total resident population of the region.

The index was calculated twice: for shops and for their surface areas. As we will see, this determines a different geography of situations of deficit and surplus of food supply in the period 2003-2019. Consideration was given to all types of sales structure identified by the "Bersani Decree": small shops, MSS and LSS: for this reason, in calculating the RCI, it is necessary to consider

\footnotetext{
${ }^{6}$ The index appears for the first time in the Three-year programme for the development of the trade sector 2006-2008; it considers the entire distribution network with the calculation of "theoretical shops" and identifies six criticality thresholds. The index does not establish a ranking for access to funding.
} 
the surface areas and not just the number of shops? ${ }^{7}$. We do not put forward an accurate measure of food deserts, but we identify at least the most problematic situations (with even significant deficits), which may conceal these phenomena. Besides, the identification of food deserts is affected by many methodological issues and would require a direct comparison with the locations and people's perceptions (Hubley 2011; McEntee, Agyeman 2010; Shaw 2006; Skarkey 2009; Ver Ploeg et al. 2015; Yeager, Gatrell 2014). The application of the RCI to the administrative grid of the municipalities could arouse perplexities, given their different extension and the more or less dispersed structure of settlements. However, in Italy, municipalities are the basic unit of territorial governance and they have important duties also in the policies for the distribution network.

The data highlight a difference between the food sector and trade as a whole, as regards consistency and evolution of situations of deficit and surplus of supply (Tab. 5). It is reasonable to assume that many municipalities have a surplus in food, all the more so in a place dominated by small inhabited centres. Food stores follow the population and are widespread in the territory, while the supply of other goods is rarer and is polarised in the larger urban centres. The data confirm this. Looking at food shops, a significant decline in cases of surplus can be seen: in 2003 they involved $53.5 \%$ of the municipalities of Lower Lombardy, but then the share dropped, becoming a minority (34.4\% in 2019). The demographic figure should not be overlooked: in 2019, just over half of the population lived in municipalities in surplus, but the value had reduced compared to 2003 when it was $60.3 \%$. The differential between the population in situations of surplus and deficit, at the start of the period in question equal to 20 pp. reduced to just $4 \mathrm{pp}$. This is a picture that makes you think: in Lower Lombardy, the transformation of trade was intense even before the "Bersani Decree", but only in the liberalist season opened by the latter did the relationships of strength overturn. The municipalities in deficit grew, until becoming prevalent, and even those not having any supply increased (food deserts in the literal sense).

While, for the food sector, there was a profound change, for trade as a whole the variations were less drastic. As early as in 2003 the majority of municipalities displayed a deficit of supply and, over time, the values increased slightly. Looking at the demographic figures, there is greater balance between situations of deficit and of surplus, but the former became prevalent. The general picture does not change - other than a different scale of values - applying the RCI to sales surface are-

${ }^{7}$ Bilkova et al. (2018) consider, on the other hand, only shops. as. In this case, the influence of a distribution network connoted by the significant presence (compared to the region) of shops with small surface areas is strongly felt.

Deepening the analysis on the coverage of food shops, some differences emerge at provincial scale (Tab. 6). In 2003, the cases of surplus were prevalent in all provinces except Lodi, reaching a maximum share in Mantua. Only in this latter place did the situations of surplus, albeit reducing, remain the majority. Mantua, in addition, is the only province in which all municipalities have a food supply. Those particular aspects are attributable to the higher demographic size of the inhabited centres and the greater distances that separate them.

In 2003, the municipalities with a deficit of supply increased in the territorial bracket close to Milan. Here, intense demographic growth was recorded, but the daily mobility outside the municipalities for work reasons is also much higher. This may have strengthened out-shopping practices for foodstuffs, depressing the development of supply locally. There are many cases of deficit also around the capitals and centre municipalities. This is not surprising: these centres have a rather substantial surplus - which reflects their historical territorial centrality - and they exercise an "agglomerations shadow" effect on the surrounding areas. In the belts, as early as in 2003 , the municipalities in surplus were less than half of the total (48.3\%) and they halved over the next 16 years (24.6\% in 2019). This is due also to the establishment, in the belts, of large commercial structures that compressed (cannibalised) the local shops. In 2019, the situations of deficit - having become prevalent - are arranged in the territory to design broad and compact fields. The cases of surplus are thinning out: they coincide with the capitals, with almost all centre-municipalities, as well as with some small and peripheral centres, where isolation and tourism have sustained local supply.

Considering the sales surfaces, the picture changes significantly due to the large presence of small shops and a development model focused on large-scale retail (Tab. 7). In 2003, only a small part of the municipalities boasted a surplus of supply (19.3\%) and the share remained stable over time. However, a good part of the population of Lower Lombardy is concentrated here. For the higher presence of cases of surplus, places that can rely upon a network of structures with larger surface areas stand out. So, the province of Lodi, which, in the ranking relating to shops was in the last position, is placed immediately after Mantua. The latter confirms its singular position: in the long-term, it retains the highest share of municipalities in surplus (approximately $40 \%$ of the total), with a significant detachment from Pavia and above all from Cremona. 
From the aggregated data at provincial scale, no significant changes over time emerge. However, the positions of the municipalities have changed. The relationships internal to the area have been redefined. An initial clear aspect concerns the gap between large and small municipalities, strengthening between 2003 and 2019. In the larger centres ( $>5,000$ inhab.) there was an increase in situations of surplus, already preponderant in the higher demographic classes (municipalities with over 10,000 inhab.). This is linked to the number of their stores, but it is above all thanks to the location of MSS and LSS that these municipalities find themselves in an advantageous position (surplus) compared to the smaller centres $(<5,000$ inhab.), where situations of deficit prevail and tend to increase. A further clear aspect concerns the centre/periphery hierarchy. It is rare to find capitals and centres in deficit. In fact, these cases have reduced until almost disappearing. Conversely, in the belts and in the even more external areas, situations of deficit have an overwhelming incidence and there are even places devoid of trade. Overall, a geography is outlined with broad areas in deficit. The exception is Mantua, some small isolated centres (in Oltrepò Pavese, in Lomellina), the capitals, centres and municipalities which have invested more than others in largescale retail (particularly in the belts surrounding Lodi and Mantua).

From the data discussed thus far, it is clear that cases of deficit have increased until involving a good part of the population and municipalities of Lower Lombardy. But what is the level of under-supply of food? In tab. 8 the cases of deficit are ranked so that their severity can be assessed. In particular, the value $100 \%$ indicates an offer equal to half of the theoretical level that the municipality should have based upon its population. In addition to heterogeneity in the levels of under-supply, the increase in situations of most criticality stands out: in the higher classes of tab. 8 there are increasing shares of municipalities and of population. It remains to be seen to what extent this is a problem. People, even for purchases of foodstuffs, are more mobile than in the past, less interested in shops near to home. However, the figures show a significant rarefaction of supply. The upheaval of old principles which guided the localisation of small grocery shops has been strong, even after the liberalisation of trade.

The presence of double deficit situations is significant (for shops and surface areas). Together with municipalities devoid of trade, these are the places closest to food deserts. They increased between 2003 and 2019, until involving $52.6 \%$ of municipalities and $34.6 \%$ of the population.

\section{Conclusions}

Lower Lombardy is also affected by this process of reduction of the distribution network which in developed countries is striking many rural areas, weak links in the geography of trade compared to other more resilient territories. Despite the change incited by the "Bersani Decree", the variation of local units and workers continues to mark worse performances than the regional ones, with growing divides over time. In the space of about twenty years, a significant erosion of proximity services has been recorded. Cases of deficit in the food supply have increased, until involving, in 2019, over half of the municipalities and a significant portion of the population. Municipalities devoid of trade have also increased, together with those having a double deficit (under-supply of shops and of surface areas), places that are close to food deserts. All this raises a question on the level of policies: in Lower Lombardy 41 trade districts have been established, but the capacity to protect shops, as a whole, has been modest. The demographic decline of many municipalities, along with the vicinity to Milan - which encourages out-shopping - compress the local distribution networks. However, the trajectories of trade transformation, south of Lombardy, are not homogeneous. At provincial scale, Mantua is a case apart, bolstered by better performances. There are also clear differences between municipalities based upon their demographic size and their position in the urban network. The smaller and peripheral municipalities have a distribution network with more traditional traits and they suffer greater difficulties. In the capitals and in the centres, and their respective belts, on the other hand, the performances are better. These places have attracted large-scale retail, with a play of centrifugal and centripetal forces that has determined a particular situation in the regional context: the centre/periphery hierarchy has not completely dissolved. A comparison with other rural areas - not just Lombardy - would be very useful to build a comprehensive picture of the different trade development models. The impact of e-commerce is another topic to consider in future research although it is currently stronger in the non-food sector. Even considering the small distribution sector, the presence, within a strong region such as Lombardy, of significant differences between areas is confirmed: a challenge for the policymakers beset by the problem of territorial cohesion. The restrictions on the movement of people, introduced by the Italian government following the Covid-19 health emergency, have highlighted how important it is to ensure an adequate local supply of food in each municipality. These drastic measures will also condition the slow return to normality that awaits us. 


\section{References}

Adkisson, R.V., Pallares, F.J. (2016). Retail Employment in Rural America: The Case of New Mexico. Regional Science Policy \& Practice, 8 (1-2), 75-92. DOI: 10.1111/ rsp3.12074

Amcoff, J. (2017). Food Deserts in Sweden? Access to Food Retail in 1998 and 2008. Geografiska Annaler B, 99 (1), 94-105. DOI: 10.1080/04353684.2016.1277076

Amcoff, J., Möller, P., Westholm, E. (2011). The (Un) importance of the Closure of Village Shops to Rural Migration Patterns. International Review of Retail, Distribution and Consumer Research, 21 (2), 129-143. DOI: 10.1080/09593969.2011.562678

Ayres, J., Leistritz, L., Stone, K. (1992). Rural Retail Business Survival: Implications for Community Developers. Journal of the Community Development Society, 23 (2), 11-21. DOI: $10.1080 / 15575339209489927$

Bahn, R.A., Abebe, G.K. (2017). Analysis of Food Retail Patterns in Urban, Peri-urban and Rural Settings: A Case Study from Lebanon. Applied Geography, 87, 28-44. DOI: 10.1016/j.apgeog.2017.07.010

Balducci, A., Fedeli, V., Curci, F. (Eds.). (2017). Oltre la metropoli. Lurbanizzazione regionale in Italia. Milano, Guerini e Associati.

Behjat, A., Ostry, A., Miewald, C., Pauly, B. (2017). Assessing the Methods in Identifying Rural Food Deserts: A Quantitative Systematic Review. American Journal of Agricultural Research, 2 (9), 1-16. DOI:10.28933/ajar2017-09-0801

Bilková, K., Križan, F., Horňák, M., Barlík, P., Zubriczký, G. (2018). Food and Non-food Retail Change in a Postcommunist Country: A Case study of the Gemer Region in Slovakia. Bulletin of Geography. Socio-economic Series, 39, 7-20. DOI: $10.2478 /$ bog-2018-0001

Blanchard, T., Lyson, T. (2002). Access to Low Cost Groceries in Nonmetropolitan Counties: Large Retailers and the Creation of Food Deserts. http://srdc.msstate.edu/measuring/blanchard.pdf

Borchert, J.G. (1998). Spatial Dynamics of Retail Structure and the Venerable Retail Hierarchy. GeoJournal, 45 (4), 327-336. DOI: 10.1023/A:1006976407047

Broadbridge, A., Calderwood, E. (2002). Rural Grocery Shoppers: Do Their Attitudes Reflect Their Actions? International Journal of Retail \& Distribution Management, 30 (8), 394-406. DOI: 10.1108/09590550210435282

Byrom, J., Medway, D., Warnaby, G. (2003). Strategic
Alternatives for Small Retail Businesses in Rural Areas. Management Research News, 26 (7), 33-49. DOI: 10.1108/01409170310783574

Cabras, I., Lau, C.K.M. (2019). The Availability of Local Services and its Impact on Community Cohesion in Rural Areas: Evidence from the English Countryside. Local Economy, 34 (3), 248-270. DOI: 10.1177/2F0269094219831951

Chaze, M. (2017). Les petites villes: pôles commerciaux en déclin ou centralités d'avenir? Territoire en Mouvement. Revue de Géographie et d'Aménagement, 33, 1-14. DOI: $10.4000 /$ tem.4026

Clerici, M.A. (2019). Competere nel commercio. Milano e le città medie fra deregulation e grande recessione. Milano, FrancoAngeli.

Dematteis, G., Emanuel, C. (1990). Reti urbane minori e deconcentrazione metropolitana nella Padania centrooccidentale. In Martellato, D., Sforzi, F. (Eds.). Studi sui sistemi urbani. Milano, FrancoAngeli, 233-261.

Emanuel, C. (1990). Integrazione urbana e nuove gerarchie di uno spazio regionale: la Padania centro-occidentale. In Innocenti, P., Paloscia, R. (Eds.). La riqualificazione delle aree metropolitane. Milano, FrancoAngeli, 169187.

ESPON (2013). European Development Opportunities for Rural Areas (EDORA), Final report. Luxembourg, ESPON.

Fertner, C., Groth, N.B., Herslund, L., Carstensen, T.A. (2015). Small Towns Resisting Urban Decay Through Residential Attractiveness. Findings from Denmark. Geografisk Tidsskrift-Danish Journal of Geography, 115 (2), 119-132. DOI: 10.1080/00167223.2015.1060863

Furey, S., Strugnell, C., McIlveen, H. (2001). An Investigation of the Potential Existence of Food Deserts in Rural and Urban Areas of Northern Ireland. Agriculture and Human Values, 18 (4), 447-457. DOI: 10.1023/A:1015218502547

Hubley, T.A. (2011). Assessing the Proximity of Healthy Food Options and Food Deserts in a Rural Area in Maine. Applied Geography, 31 (4), 1224-1231. DOI: 10.1016/j. apgeog.2010.09.004

Karlsson, E.B. (2012). Retail in Rural Regions. Exploring Ways to Support Rural Shops. Bifröst, Centre for Retail Studies, Bifröst University (Iceland). http://www.rsv.is/ files/Skra_0060124.pdf

Mainardi, R. (1997). L'Italia delle regioni. Il Nord e la Padania. Milano, Bruno Mondadori. 
Marjanen, H. (2000). Retailing in Rural Finland and the Challenge of Nearby Cities. International Journal of Retail \& Distribution Management, 28 (4-5), 194-206. DOI: 10.1108/09590550010319940

Marshall, D., Dawson, J., Nisbet, L. (2018). Food access in remote rural places: consumer accounts of food shopping. Regional Studies, 52 (1), 133-144. DOI: 10.1080/00343404.2016.1275539

Massal, C. (2018). La fin des commerces de proximité dans les campagnes françaises? Géoconfluences. http:// geoconfluences.ens-lyon.fr/informations-scientifiques/ dossiers-regionaux/france-espaces-ruraux-periurbains/ articles-scientifiques/disparition-commerces-proximite

McEachern, M.G., Warnaby, G. (2006). Food Shopping Behaviour in Scotland: The Influence of Relative Rurality. International Journal of Consumer Studies, 30 (2), 189201. DOI: $10.1111 /$ j.1470-6431.2005.00475.x

McEntee, J., Agyeman, J. (2010). Towards the Development of a GIS Method for Identifying Rural Food Deserts: Geographic access in Vermont, USA. Applied Geography, 30 (1), 165-176. DOI: 10.1016/j.apgeog.2009.05.004

Meijers, E.J., Burger, M.J. (2017). Stretching the Concept of "Borrowed size". Urban Studies, 54 (1), 269-291. DOI: 10.1177/2F0042098015597642

Morandi, C. (2005). Misure di valorizzazione e integrazione della rete dei servizi commerciali nelle aree montane. In Adobati, F., Oliveri, A., Tamini, L. (Eds.). Commercio e politiche territoriali: 4 temi emergenti. Bergamo, University Press, 21-26.

Mullis, K., Kim, M. (2011). Factors Determining Inshopping in Rural US Communities. Consumers' and Retailers' Perceptions. International Journal of Retail \& Distribution Management, 39 (5), 326-345. DOI: 10.1108/09590551111130757

OECD (2010). Strategies to Improve Rural Service Delive$r y$. Paris, OECD.

Paddison, A., Calderwood, E. (2007). Rural Retailing: A Sector in Decline? International Journal of Retail \& Distribution Management, 35 (2), 136-155. DOI: 10.1108/09590550710728093

Pilotti, L., Giovanelli, A. (2010). La riqualificazione dei centri storici nelle zone di montagna. Dalle linee guida della Provincia autonoma di Bolzano al progetto pilota del comune di Egna-Neumarkt. Milano, FrancoAngeli.

Powe, N., Hart, T., Shaw, T. (Eds.). (2007). Market Towns. Roles, Challenges and Prospects. London and New York, Routledge.
Preite, M. (Ed.) (2003). Un commercio di qualità per lo sviluppo sostenibile della montagna. Il caso dell'Amiata grossetano. Firenze, Alinea.

Scarpello, T., Poland, F., Lambert, N., Wakeman, T. (2009). A Qualitative Study of the Food related Experiences of Rural Village Shop Customers. Journal of Human Nutrition and Dietetics, 22 (2), 108-115. DOI: 10.1111/j.1365-277X.2008.00940.x

Shannon, J. (2016). Beyond the Supermarket Solution: Linking Food Deserts, Neighborhood Context, and Everyday Mobility. Annals of the American Association of Geographers, 106 (1), 186-202. DOI: 10.1080/00045608.2015.1095059

Sharkey, J.R. (2009). Measuring Potential Access to Food Stores and Food-Service Places in Rural Areas in the U.S. American Journal of Preventive Medicine, 36 (4 suppl.), S151-S155. DOI: 10.1016/j.amepre.2009.01.004

Shaw, H.J. (2006). Food deserts: Towards the Development of a Classification. Geografiska Annaler B, 88 (2), 231-247. DOI: 10.1111/j.0435-3684.2006.00217.x

Smith, C., Morton, L.W., (2009). Rural Food Deserts: Low-income Perspectives on Food Access in Minnesota and Iowa. Journal of Nutrition Education and Behavior, 41 (3), 176-187. DOI: 10.1016/j.jneb.2008.06.008

Turri, E. (2000). La megalopoli padana. Venezia, Marsilio.

Twardzik, M., Heffner, K. (2019). Small Towns and Rural Areas - As a Prospective Place of Modern Retail Trade Formats in Poland. European Countryside, 11 (1), 74-84. DOI: 10.2478/euco-2019-0005

van Leeuwen, E.S., Rietveld, P. (2011). Spatial Consumer Behaviour in Small and Medium-Sized Towns. Regional Studies, 45 (8), 1107-1119. DOI: $10.1080 / 00343401003713407$

Ver Ploeg, M., Dutko, P., Breneman, V. (2015). Measuring Food Access and Food Deserts for Policy Purposes. Applied Economic Perspectives and Policy, 37 (2), 205-225. DOI: 10.1093/aepp/ppu035

Vias, A.C. (2004). Bigger Stores, More Stores, or no Stores: Paths of Retail Restructuring in Rural America. Journal of Rural Studies, 20 (3), 303-318. DOI: 10.1016/j. jrurstud.2003.10.003

Viviano, E. (2008). Entry Regulations and Labour Market Outcomes: Evidence from the Italian Retail Trade Sector. Labour Economics, 15 (6), 1200-1222. DOI: 10.1016/j. labeco.2007.11.004 
Woods, M. (2005). Rural Geography. Processes, Responses and Experiences in Rural Restructuring. London, Sage.

Wrigley, N. (2002). Food Deserts in British Cities: Policy Context and Research Priorities. Urban Studies, 39 (11), 2029-2040. DOI: 10.1080/0042098022000011344

Wrigley, N., Lowe, M. (Eds.). (2002). Reading Retail. A Geographical Perspective on Retailing and Consumption Spaces. London, Arnold.

Yeager, C.D., Gatrell, J.D. (2014). Rural Food Accessibility: An Analysis of Travel Impedance and the Risk of Potential Grocery Closures. Applied Geography, 53, 1-10. DOI: $10.1016 /$ j.apgeog.2014.05.018 
Table 1. Lower Lombardy: general data, 2019. Source: author's elaboration on ISTAT and OECD.

\begin{tabular}{|c|c|c|c|c|c|c|}
\hline \multirow{2}{*}{ Variables } & \multicolumn{5}{|c|}{ Provinces } & \multirow{2}{*}{ Lombardy } \\
\hline & Pavia & Lodi $^{1}$ & Cremona & Mantua & Total & \\
\hline Municipalities, $\mathrm{N}^{\circ}$ & 186 & 61 & 113 & 64 & 424 & 1,507 \\
\hline Inhabitants, $\mathrm{N}^{\circ}$ & 545,888 & 237,628 & 358,955 & 412,292 & $1,554,763$ & $10,060,574$ \\
\hline Inhab./ $\mathrm{Km}^{2}$ & 183.9 & 297.2 & 202.7 & 176.1 & 197.3 & 421.6 \\
\hline Municipalities $<5,000$ inhab., $\%$ & 87.1 & 85.2 & 89.4 & 54.7 & 82.5 & 68.7 \\
\hline $\begin{array}{l}\text { Resident population in municipalities } \\
<5,000 \text { inhab., } \%\end{array}$ & 39.1 & 47.5 & 46.8 & 21.0 & 37.4 & 20.5 \\
\hline $\begin{array}{l}\text { Resident population in nuclei and scattered } \\
\text { houses }^{2}, \%\end{array}$ & 7.9 & 4.7 & 5.2 & 13.2 & 8.2 & 3.7 \\
\hline Value added ${ }^{3}, \mathrm{mln}$. Euro & $12,070.3$ & $5,463.5$ & $10,234.7$ & $11,725.2$ & $39,493.7$ & $348,097.6$ \\
\hline Primary sector, \% & 2.6 & 3.6 & 5.2 & 6.2 & 4.5 & 1.1 \\
\hline Secondary sector, $\%$ & 27.1 & 28.0 & 33.0 & 34.8 & 31.0 & 26.8 \\
\hline Tertiary sector, $\%$ & 70.3 & 68.4 & 61.8 & 59.0 & 64.5 & 72.1 \\
\hline $\begin{array}{l}\text { Mobility outside the municipalities }{ }^{2} \text {, } \\
\text { median, } \%\end{array}$ & 46.8 & 50.7 & 47.0 & 36.1 & 45.0 & 46.3 \\
\hline Regional typology (Oecd) & Intermediate & Intermediate & Intermediate & Intermediate & - & - \\
\hline
\end{tabular}

${ }^{1}$ Including San Colombano al Lambro (province of Milan), with the exception of data on value added. ${ }^{2}$ In $2011 .{ }^{3}$ In 2017 , current prices.

Table 2. Retail trade in Lower Lombardy, 2001-2017. Source: author's elaboration on ISTAT.

\begin{tabular}{|c|c|c|c|c|c|c|c|c|}
\hline \multirow[b]{2}{*}{ Areas } & \multicolumn{2}{|c|}{ Local units } & \multicolumn{2}{|c|}{ Workers } & \multicolumn{2}{|c|}{$\Delta \%$ Local units } & \multicolumn{2}{|c|}{$\Delta \%$ Workers } \\
\hline & $\begin{array}{c}\mathrm{N}^{\circ} \\
2001\end{array}$ & $\begin{array}{c}\mathrm{N}^{\circ} \\
2017\end{array}$ & $\begin{array}{c}\mathrm{N}^{\circ} \\
2001\end{array}$ & $\begin{array}{c}\mathrm{N}^{\circ} \\
2017^{3}\end{array}$ & $\begin{array}{c}2001- \\
2011\end{array}$ & $\begin{array}{l}2012- \\
2017\end{array}$ & $\begin{array}{l}2001- \\
2011\end{array}$ & $\begin{array}{l}2012- \\
2017^{3}\end{array}$ \\
\hline \multicolumn{9}{|c|}{ Provinces } \\
\hline Pavia & 6,323 & 4,918 & 14,972 & 14,585 & -14.2 & -9.4 & 2.7 & -3.6 \\
\hline Lodi $^{1}$ & 2,222 & 1,889 & 6,115 & 6,547 & -8.6 & -8.7 & 8.7 & -5.9 \\
\hline Cremona & 3,866 & 3,272 & 9,240 & 9,582 & -8.7 & -8.1 & 7.8 & -3.4 \\
\hline Mantua & 4,887 & 4,126 & 11,224 & 12,921 & -15.5 & -8.2 & 9.3 & 3.7 \\
\hline \multicolumn{9}{|c|}{ Categories of municipalities } \\
\hline Provincial capital & 3,395 & 2,811 & 9,192 & 9,136 & -13.5 & -7.4 & 8.9 & -9.9 \\
\hline Centre & 4,682 & 4,052 & 11,882 & 13,608 & -8.7 & -7.1 & 13.9 & 1.6 \\
\hline Belt & 3,272 & 2,746 & 8,953 & 9,750 & -11.2 & -8.3 & 7.5 & 0.1 \\
\hline Other & 5,949 & 4,596 & 11,524 & 11,141 & -16.0 & -11.0 & -3.8 & -0.4 \\
\hline \multicolumn{9}{|c|}{ Demographic classes of municipalities ${ }^{2}$} \\
\hline$<1,000$ inhab. & 611 & 398 & 841 & 660 & -21.8 & -15.9 & -1.8 & -20.5 \\
\hline $1,000-3,000$ & 3,019 & 2,373 & 7,297 & 6,924 & -13.2 & -10.6 & -1.3 & -5.1 \\
\hline $3,000-5,000$ & 1,693 & 1,321 & 3,871 & 3,726 & -12.8 & -10.7 & -1.3 & -3.2 \\
\hline $5,000-10,000$ & 3,898 & 3,250 & 8,468 & 9,580 & -14.6 & -8.5 & 4.6 & 7.0 \\
\hline $10,000-20,000$ & 2,076 & 1,820 & 5,270 & 6,057 & -6.9 & -6.7 & 15.6 & -1.0 \\
\hline$>20,000$ & 6,001 & 5,043 & 15,804 & 16,688 & -12.0 & -7.4 & 10.4 & -4.2 \\
\hline$<5,000$ & 5,323 & 4,092 & 12,009 & 11,310 & -14.1 & -11.6 & -1.3 & -5.6 \\
\hline$>5,000$ & 11,975 & 10,113 & 29,542 & 32,325 & -12.0 & -7.6 & 9.7 & -0.5 \\
\hline Total area & 17,298 & 14,205 & 41,551 & 43,635 & -12.6 & -8.7 & 6.5 & -1.9 \\
\hline Total Lombardy & 98,805 & 88,692 & 273,778 & 317,738 & -8.2 & -4.3 & 14.2 & 2.3 \\
\hline
\end{tabular}

${ }^{1}$ Included San Colombano al Lambro (province of Milan). ${ }^{2}$ In 2019. ${ }^{3}$ Calculated on average annual data. 
Table 3. Medium and large sales structures in the provinces of Lower Lombardy, 2003-2019 ${ }^{1}$. Source: author's elaboration on ISTAT and Trade Observatory for the Lombardy region.

\begin{tabular}{|c|c|c|c|c|c|c|c|c|}
\hline \multirow[b]{2}{*}{ Areas } & \multicolumn{4}{|c|}{ Food sector } & \multicolumn{4}{|c|}{ Total } \\
\hline & $\begin{array}{l}\text { sqm } \\
2019\end{array}$ & $\begin{array}{c}\text { Balance sqm } \\
\text { 2003-2019 }\end{array}$ & $\begin{array}{c}\Delta \% \text { sqm } \\
2003-2019\end{array}$ & $\begin{array}{c}\text { sqm/1,000 } \\
\text { inhab., } 2019\end{array}$ & $\begin{array}{l}\text { sqm } \\
2019\end{array}$ & $\begin{array}{c}\text { Balance sqm } \\
2003-2019\end{array}$ & $\begin{array}{c}\Delta \% \text { sqm } \\
2003-2019\end{array}$ & $\begin{array}{c}\text { sqm/1,000 } \\
\text { inhab., } 2019\end{array}$ \\
\hline \multicolumn{9}{|c|}{ Medium sales structures } \\
\hline Pavia & 87,963 & 34,375 & 64.1 & 161.1 & 328,740 & 89,107 & 37.2 & 602.2 \\
\hline Lodi $^{2}$ & 36,518 & 13,397 & 57.9 & 153.7 & 137,594 & 36,018 & 35.5 & 579.0 \\
\hline Cremona & 53,019 & 20,362 & 62.4 & 147.7 & 225,404 & 81,398 & 56.5 & 627.9 \\
\hline Mantua & 87,641 & 28,337 & 47.8 & 212.6 & 325,894 & 61,284 & 23.2 & 790.4 \\
\hline Total area & 265,141 & 96,471 & 57.2 & 170.5 & $1,017,632$ & 267,807 & 35.7 & 654.5 \\
\hline Lombardy & $1,503,508$ & 530,474 & 54.5 & 149.4 & $5,672,291$ & $1,259,005$ & 28.5 & 563.8 \\
\hline \multicolumn{9}{|c|}{ Large sales structures } \\
\hline Pavia & 47,667 & 3,832 & 8.7 & 87.3 & 160,485 & 1,103 & 0.7 & 294.0 \\
\hline Lodi $^{2}$ & 26,110 & 4,730 & 22.1 & 109.9 & 107,409 & 12,153 & 12.8 & 452.0 \\
\hline Cremona & 21,696 & $-1,808$ & -7.7 & 60.4 & 92,138 & -131 & -0.1 & 256.7 \\
\hline Mantua & 46,778 & 13,897 & 42.3 & 113.5 & 155,353 & 22,225 & 16.7 & 376.8 \\
\hline Total area & 142,251 & 20,651 & 17.0 & 91.5 & 515,385 & 35,350 & 7.4 & 331.5 \\
\hline Lombardy & 888,946 & 194,211 & 28.0 & 88.4 & $4,011,907$ & $1,205,547$ & 43.0 & 398.8 \\
\hline
\end{tabular}

${ }^{1}$ Medium sales structures: $150-1,500 \mathrm{sqm}$ in the municipalites up to 10,000 inhabitants and 250-2,500 sqm in the other municipalities. Large sales structures: over 1,500 sqm in the municipalities up to 10,000 inhabitants and over 2,500 sqm in the other municipalities. ${ }^{2}$ Included San Colombano al Lambro (province of Milan).

Table 4. Medium and large food sales structures in Lower Lombardy, 2003-2019. Source: author's elaboration on Trade Observatory for the Lombardy region.

\begin{tabular}{|c|c|c|c|c|c|c|c|c|}
\hline \multirow[b]{2}{*}{ Municipalities $^{1}$} & \multicolumn{4}{|c|}{ Medium sales structures $^{2}$} & \multicolumn{4}{|c|}{ Large sales structures ${ }^{2}$} \\
\hline & $\begin{array}{l}\text { sqm } \\
2019\end{array}$ & $\begin{array}{c}\text { Balance sqm } \\
2003-2019\end{array}$ & $\begin{array}{l}\text { \% sqm } \\
2003\end{array}$ & $\begin{array}{l}\text { \% sqm } \\
2019\end{array}$ & $\begin{array}{l}\text { sqm } \\
2019\end{array}$ & $\begin{array}{c}\text { Balance sqm } \\
2003-2019\end{array}$ & $\begin{array}{l}\% \text { sqm } \\
2003\end{array}$ & $\begin{array}{c}\text { \% sqm } \\
2019\end{array}$ \\
\hline \multicolumn{9}{|c|}{ Categories of municipalities } \\
\hline Provincial capital & 57,335 & 20,529 & 21.8 & 21.6 & 22,170 & 1,955 & 16.6 & 15.6 \\
\hline Centre & 87,360 & 23,895 & 37.6 & 32.9 & 53,012 & 12,672 & 33.2 & 37.3 \\
\hline Belt & 42,968 & 15,799 & 16.1 & 16.2 & 48,208 & 2,677 & 37.4 & 33.9 \\
\hline Other & 77,478 & 36,248 & 24.4 & 29.2 & 18,861 & 3,347 & 12.8 & 13.3 \\
\hline \multicolumn{9}{|c|}{ Demographic classes of municipalities ${ }^{3}$} \\
\hline$<1,000$ inhab. & 1,233 & 811 & 0.3 & 0.5 & - & - & - & - \\
\hline $1,000-3,000$ & 14,677 & 5,356 & 5.5 & 5.5 & 39,563 & 1,117 & 31.6 & 27.8 \\
\hline $3,000-5,000$ & 19,576 & 8,132 & 6.8 & 7.4 & 8,019 & - & 6.6 & 5.6 \\
\hline $5,000-10,000$ & 84,960 & 37,748 & 28.0 & 32.0 & 19,487 & 4,907 & 12.0 & 13.7 \\
\hline $10,000-20,000$ & 47,521 & 19,115 & 16.8 & 17.9 & 26,480 & 10,557 & 13.1 & 18.6 \\
\hline$>20,000$ & 97,174 & 25,309 & 42.6 & 36.6 & 48,702 & 4,070 & 36.7 & 34.2 \\
\hline$<5,000$ & 35,486 & 14,299 & 12.6 & 13.4 & 47,582 & 1,117 & 38.2 & 33.4 \\
\hline$>5,000$ & 229,655 & 82,172 & 87.4 & 86.6 & 94,669 & 19,534 & 61.8 & 66.6 \\
\hline Total area & 265,141 & 96,471 & 100.0 & 100.0 & 142,251 & 20,651 & 100.0 & 100.0 \\
\hline
\end{tabular}

\footnotetext{
${ }^{1}$ Included San Colombano al Lambro (province of Milan). ${ }^{2}$ For dimensional limits, see table 3. ${ }^{3}$ In 2019.
} 
Table 5. Retail Capacity Index in Lower Lombardy: general picture, 2003-2019. Source: author's elaboration on ISTAT and Trade Observatory for the Lombardy region.

\begin{tabular}{|c|c|c|c|c|c|c|}
\hline \multirow{2}{*}{ Cases } & \multicolumn{3}{|c|}{$\%$ Municipalities $(100 \%=424)^{1}$} & \multicolumn{3}{|c|}{$\%$ Resident population } \\
\hline & 2003 & 2011 & 2019 & 2003 & 2011 & 2019 \\
\hline \multicolumn{7}{|c|}{ Food: stores } \\
\hline Without offer & 4.5 & 3.3 & 6.1 & 0.5 & 0.2 & 0.6 \\
\hline Deficit & 42.0 & 52.4 & 59.4 & 39.2 & 38.6 & 47.6 \\
\hline Surplus & 53.5 & 44.3 & 34.4 & 60.3 & 61.1 & 51.8 \\
\hline \multicolumn{7}{|c|}{ Total: stores } \\
\hline Without offer & 4.0 & 3.1 & 5.4 & 0.4 & 0.2 & 0.5 \\
\hline Deficit & 76.9 & 78.8 & 77.6 & 47.8 & 51.6 & 53.3 \\
\hline Surplus & 19.1 & 18.2 & 17.0 & 51.8 & 48.2 & 46.3 \\
\hline \multicolumn{7}{|c|}{ Food: surface areas } \\
\hline Without offer & 4.5 & 3.3 & 6.1 & 0.5 & 0.2 & 0.6 \\
\hline Deficit & 76.2 & 75.2 & 74.3 & 53.9 & 46.0 & 44.0 \\
\hline Surplus & 19.3 & 21.5 & 19.6 & 45.6 & 53.8 & 55.4 \\
\hline \multicolumn{7}{|c|}{ Total: surface areas } \\
\hline Without offer & 4.0 & 3.1 & 5.4 & 0.4 & 0.2 & 0.5 \\
\hline Deficit & 79.0 & 80.0 & 79.0 & 49.3 & 51.4 & 55.8 \\
\hline Surplus & 17.0 & 17.0 & 15.6 & 50.3 & 48.4 & 43.8 \\
\hline
\end{tabular}

${ }^{1}$ Administrative boundaries in 2019; included San Colombano al Lambro (province of Milan). 
Table 6. Retail Capacity Index in the municipalities of Lower Lombardy: food stores, 2003-2019, val. \%. Source: author's elaboration on ISTAT and Trade Observatory for the Lombardy region.

\begin{tabular}{|c|c|c|c|c|c|c|}
\hline \multirow{2}{*}{ Areas } & \multicolumn{2}{|c|}{ Without offer } & \multicolumn{2}{|c|}{ Deficit } & \multicolumn{2}{|c|}{ Surplus } \\
\hline & 2003 & 2019 & 2003 & 2019 & 2003 & 2019 \\
\hline \multicolumn{7}{|c|}{ Provinces $($ row $=100 \%)$} \\
\hline Pavia & 7.5 & 9.7 & 33.9 & 54.3 & 58.6 & 36.0 \\
\hline Lodi $^{1}$ & 4.9 & 3.3 & 68.9 & 82.0 & 26.2 & 14.8 \\
\hline Cremona & 1.8 & 5.3 & 46.9 & 62.8 & 51.3 & 31.9 \\
\hline Mantua & - & - & 31.3 & 46.9 & 68.7 & 53.1 \\
\hline \multicolumn{7}{|c|}{ Categories of municipalities (row $=100 \%$ ) } \\
\hline Provincial capital & - & - & 25.0 & - & 75.0 & 100.0 \\
\hline Centre & - & - & 42.1 & 36.8 & 57.9 & 63.2 \\
\hline Belt & 2.5 & 3.4 & 49.2 & 72.0 & 48.3 & 24.6 \\
\hline Other & 5.7 & 7.8 & 39.2 & 56.5 & 55.1 & 35.7 \\
\hline \multicolumn{7}{|c|}{ Demographic classes of municipalities $^{2}($ row $=100 \%)$} \\
\hline$<1,000$ inhab. & 14.0 & 20.7 & 29.8 & 43.8 & 56.2 & 35.5 \\
\hline $1,000-3,000$ & 1.1 & 0.6 & 47.5 & 67.4 & 51.4 & 32.0 \\
\hline $3,000-5,000$ & - & - & 52.1 & 79.2 & 47.9 & 20.8 \\
\hline $5,000-10,000$ & - & - & 43.1 & 60.8 & 56.9 & 39.2 \\
\hline $10,000-20,000$ & - & - & 46.2 & 53.8 & 53.8 & 46.2 \\
\hline$>20,000$ & - & - & 30.0 & 10.0 & 70.0 & 90.0 \\
\hline$<5,000$ & 5.4 & 7.4 & 42.0 & 60.9 & 52.6 & 31.7 \\
\hline$>5,000$ & - & - & 41.9 & 52.7 & 58.1 & 47.3 \\
\hline Total area & 4.5 & 6.1 & 42.0 & 59.4 & 53.5 & 34.4 \\
\hline
\end{tabular}

${ }^{1}$ Included San Colombano al Lambro (province of Milan). ${ }^{2}$ Administrative boundaries in 2019. 
Table 7. Retail Capacity Index in the municipalities of Lower Lombardy: food sales surface areas, 2003-2019, val. \%. Source: author's elaboration on ISTAT and Trade Observatory for the Lombardy region.

\begin{tabular}{|c|c|c|c|c|c|c|}
\hline \multirow{2}{*}{ Areas } & \multicolumn{2}{|c|}{ Without offer } & \multicolumn{2}{|c|}{ Deficit } & \multicolumn{2}{|c|}{ Surplus } \\
\hline & 2003 & 2019 & 2003 & 2019 & 2003 & 2019 \\
\hline \multicolumn{7}{|c|}{ Provinces $($ row $=100 \%)$} \\
\hline Pavia & 7.5 & 9.7 & 75.3 & 73.1 & 17.2 & 17.2 \\
\hline Lodi $^{1}$ & 4.9 & 3.3 & 73.8 & 75.4 & 21.3 & 21.3 \\
\hline Cremona & 1.8 & 5.3 & 87.6 & 84.1 & 10.6 & 10.6 \\
\hline Mantua & - & - & 60.9 & 59.4 & 39.1 & 40.6 \\
\hline \multicolumn{7}{|c|}{ Categories of municipalities (row $=100 \%$ ) } \\
\hline Provincial capital & - & - & 25.0 & - & 75.0 & 100.0 \\
\hline Centre & - & - & 15.8 & 5.3 & 84.2 & 94.7 \\
\hline Belt & 2.5 & 3.4 & 76.3 & 78.0 & 21.2 & 18.6 \\
\hline Other & 5.7 & 7.8 & 80.9 & 78.4 & 13.4 & 13.8 \\
\hline \multicolumn{7}{|c|}{ Demographic classes of municipalities ${ }^{2}$ (row $\left.=100 \%\right)$} \\
\hline$<1,000$ inhab. & 14.0 & 20.7 & 73.6 & 72.7 & 12.4 & 6.6 \\
\hline $1,000-3,000$ & 1.1 & 0.6 & 85.6 & 88.4 & 13.3 & 11.0 \\
\hline $3,000-5,000$ & - & - & 79.2 & 81.2 & 20.8 & 18.8 \\
\hline $5,000-10,000$ & - & - & 72.5 & 52.9 & 27.5 & 47.1 \\
\hline $10,000-20,000$ & - & - & 23.1 & 7.7 & 76.9 & 92.3 \\
\hline$>20,000$ & - & - & 10.0 & - & 90.0 & 100.0 \\
\hline$<5,000$ & 5.4 & 7.4 & 80.6 & 82.0 & 14.0 & 10.6 \\
\hline$>5,000$ & - & - & 55.4 & 37.8 & 44.6 & 62.2 \\
\hline Total area & 4.5 & 6.1 & 76.2 & 74.3 & 19.3 & 19.6 \\
\hline
\end{tabular}

${ }^{1}$ Included San Colombano al Lambro (province of Milan). ${ }^{2}$ Administrative boundaries in 2019. 
Table 8. Levels of food trade deficit in Lower Lombardy, 2003-2019. Source: author's elaboration on ISTAT and Trade Observatory for the Lombardy region.

\begin{tabular}{|c|c|c|c|c|c|c|}
\hline \multirow{2}{*}{ Deficit/levels } & \multicolumn{3}{|c|}{$\%$ Municipalities $^{1}$} & \multicolumn{3}{|c|}{$\%$ Resident population } \\
\hline & 2003 & 2011 & 2019 & 2003 & 2011 & 2019 \\
\hline \multicolumn{7}{|c|}{ Deficit in stores } \\
\hline$<25 \%$ & 33.1 & 28.4 & 24.6 & 49.9 & 31.3 & 34.1 \\
\hline $25-50 \%$ & 30.3 & 24.3 & 19.4 & 25.9 & 23.2 & 18.8 \\
\hline $50-75 \%$ & 12.4 & 14.0 & 15.9 & 8.9 & 16.9 & 15.6 \\
\hline $75-100 \%$ & 8.4 & 9.0 & 10.7 & 4.6 & 6.1 & 7.4 \\
\hline$>100 \%$ & 15.7 & 24.3 & 29.4 & 10.7 & 22.5 & 24.2 \\
\hline Total & 100,0 & 100,0 & 100,0 & 100,0 & 100,0 & 100,0 \\
\hline \multicolumn{7}{|c|}{ Deficit in surface areas } \\
\hline$<25 \%$ & 13.0 & 8.2 & 9.5 & 27.0 & 15.9 & 14.3 \\
\hline $25-50 \%$ & 13.3 & 12.2 & 10.2 & 13.4 & 13.3 & 15.8 \\
\hline $50-75 \%$ & 13.9 & 11.3 & 6.7 & 12.2 & 11.8 & 8.4 \\
\hline $75-100 \%$ & 9.6 & 7.5 & 7.3 & 10.7 & 7.7 & 8.8 \\
\hline$>100 \%$ & 50.2 & 60.8 & 66.3 & 36.8 & 51.3 & 52.7 \\
\hline Total & 100.0 & 100.0 & 100.0 & 100.0 & 100.0 & 100.0 \\
\hline \multicolumn{7}{|c|}{ Cases of double deficit ${ }^{2}$} \\
\hline Pavia & 32.8 & 44.1 & 50.0 & 23.8 & 32.5 & 34.8 \\
\hline Lodi & 57.4 & 59.0 & 67.2 & 39.5 & 41.6 & 43.6 \\
\hline Cremona & 45.1 & 55.8 & 58.4 & 30.6 & 36.6 & 41.2 \\
\hline Mantua & 20.3 & 26.6 & 35.9 & 16.2 & 19.6 & 23.3 \\
\hline Total area & 37.7 & 46.7 & 52.6 & 25.7 & 31.4 & 34.6 \\
\hline
\end{tabular}

${ }^{1}$ Administrative boundaries in 2019; included San Colombano al Lambro (province of Milan). ${ }^{2}$ Excluding municipalities without offer. 


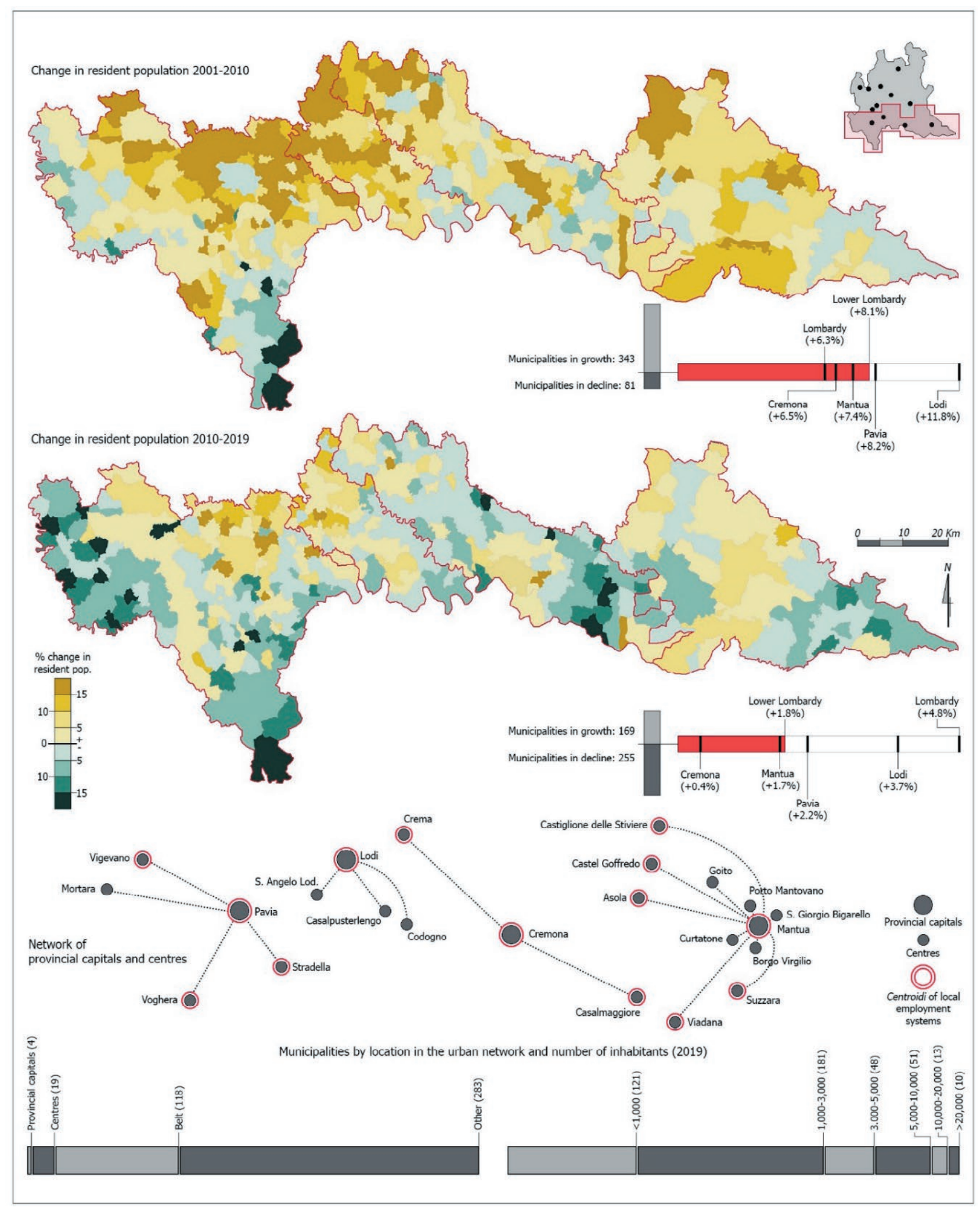

Figure 1. Variation of the resident population and type of municipalities in Lower Lombardy, 2001-2019. Source: author's elaboration on ISTAT data. 


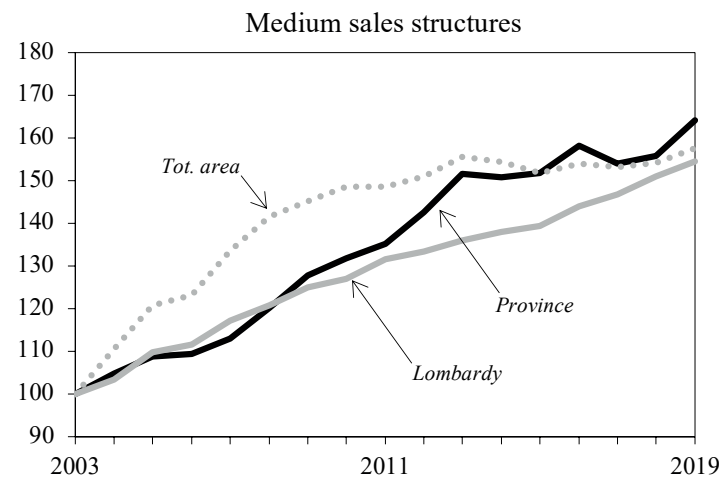

Pavia
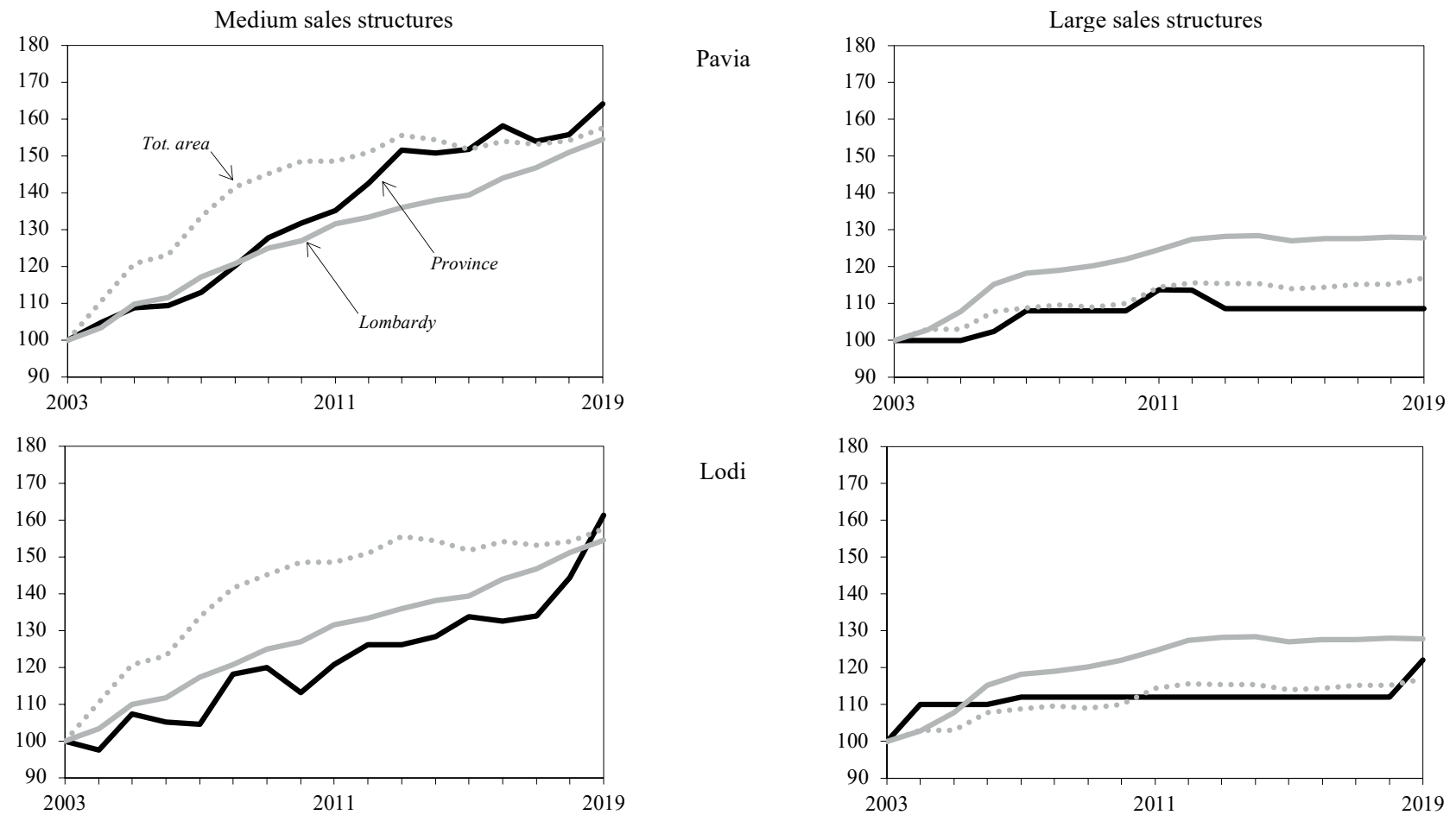

Lodi
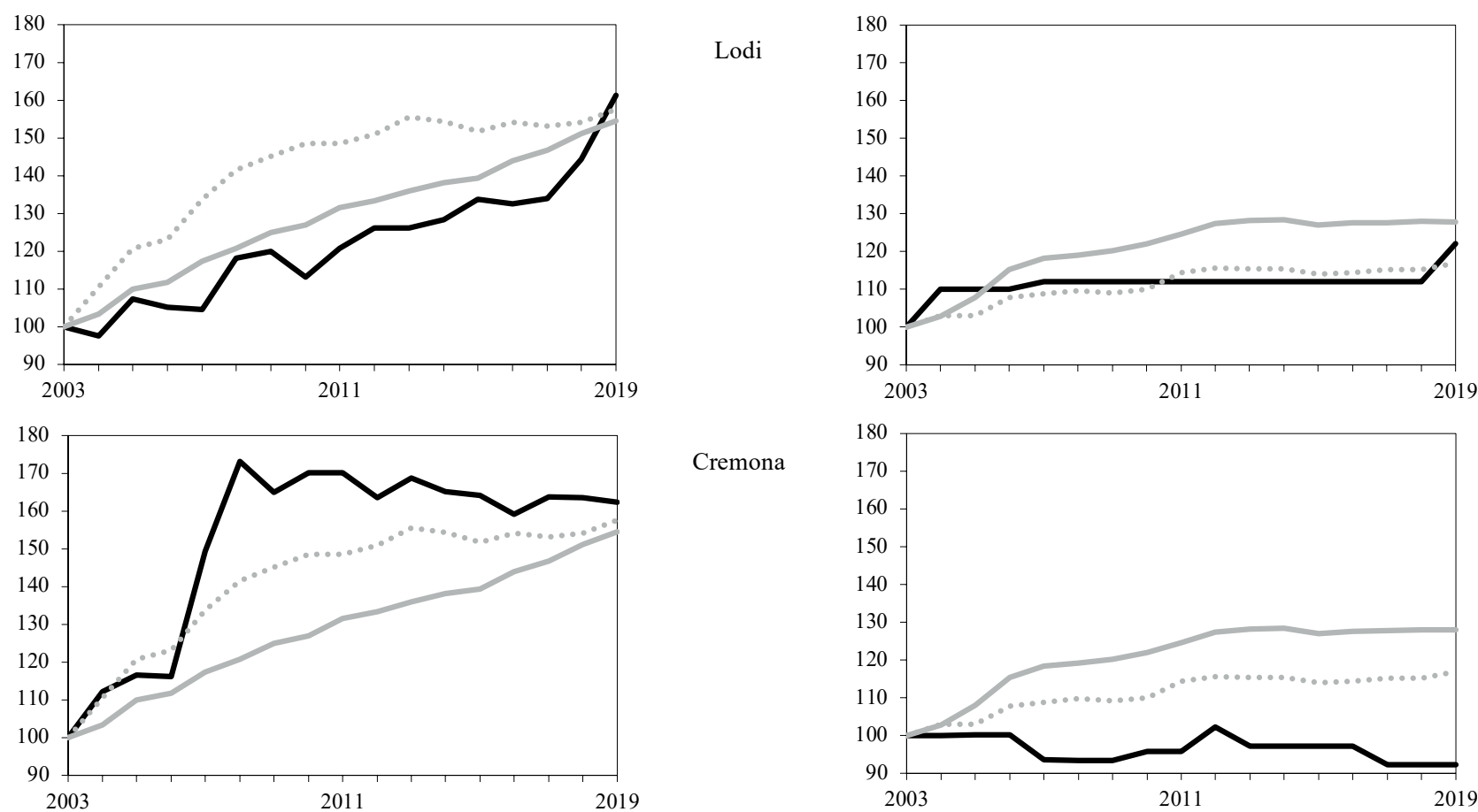

Cremona
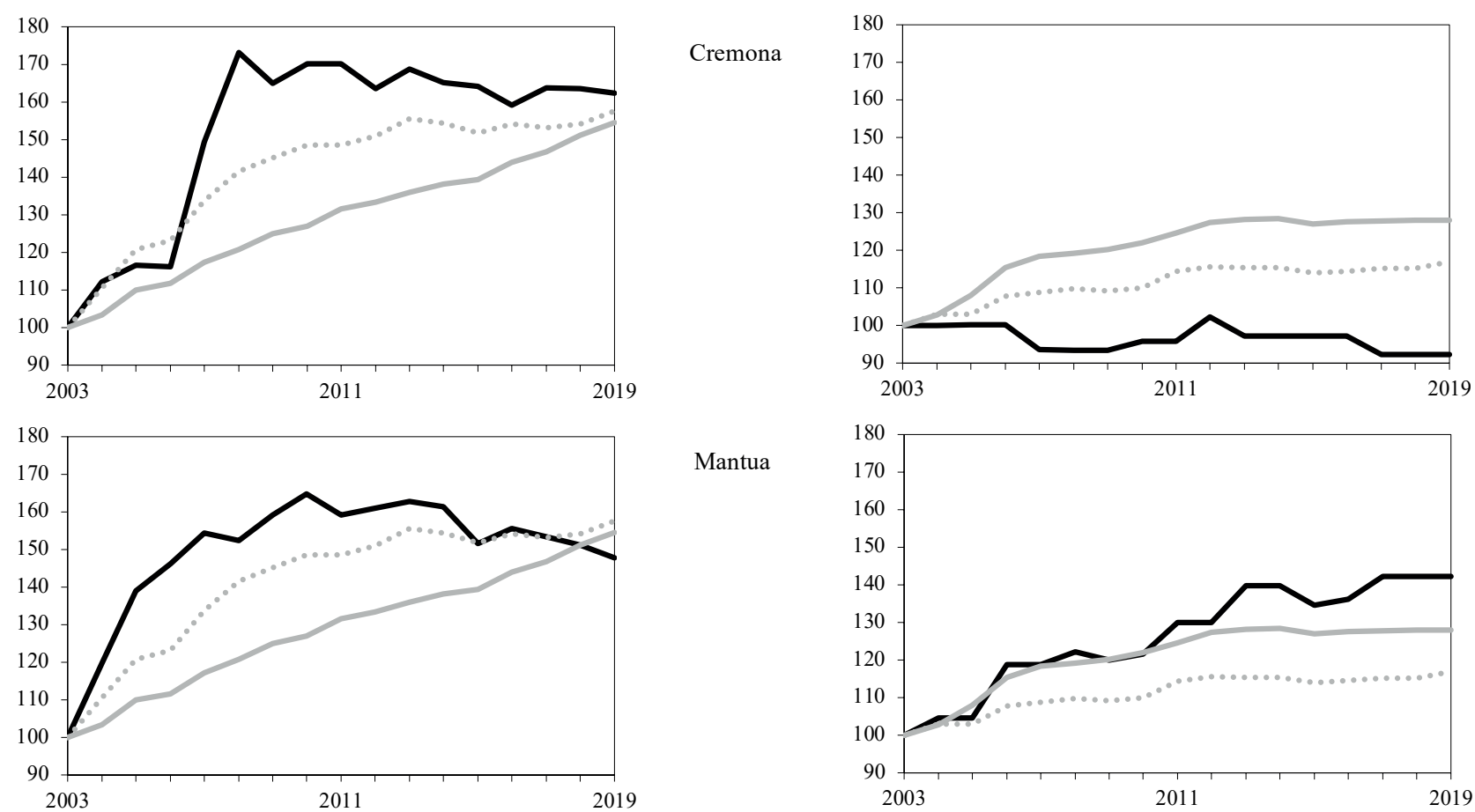

Figure 2. Trend of surface areas of medium and large food sales structures in the provinces of Lower Lombardy, 2003-2019 (indexes $2003=100$ ). Source: Trade Observatory for the Lombardy region. 